Janik B. (2014). Market and non-market factors influencing the development of green energy producers. Copernican Journal of Finance \& Accounting, 3(2), 25-36. http://dx.doi.org/10.12775/ CJFA.2014.015

\author{
BOGNA JANIK* \\ Poznan School of Banking
}

\title{
MARKET AND NON-MARKET FACTORS INFLUENCING THE DEVELOPMENT OF GREEN ENERGY PRODUCERS
}

Keywords: green energy, green energy producers, property rights, renewable energy.

J E L Classification: G32, G38.

\begin{abstract}
The aim of the study is to identify and examine some key factors crucial to the development of the Polish industry of producers obtaining renewable energy, and to find the market and non-market factors influencing the development of Polish green energy producers. What is essential for the development of renewable energy producers is an adequate public policy, especially the regulations concerning the financial aspects of obtaining energy from renewable sources and the efficiency of available technologies. Pricing mechanisms defining the company's revenue from various resources are the most important factors, however it is difficult to determine their priority. A better understanding of the conditions of the Polish renewable energy sector will also be useful in the process of public policy modifications and fostering the development of the renewable energy area. It is one of the first attempts to investigate the issues concerning financial performance of renewable energy companies on the Polish market.
\end{abstract}

\section{RYNKOWE I POZARYNKOWE CZYNNIKI ROZWOJU PRODUCENTÓW ZIELONEJ ENERGII}

Słowa kluczowe: zielona energia, producenci zielonej energii, prawa majątkowe, energia odnawialna.

Date of submission: February 27, 2014; date of acceptance: September 9, 2014.

* Contact information: bogna.janik@wsb.poznan.pl, Poznan School of Banking, Niepodległosci 2, 61-874 Poznan, Poland, phone: 602611723. 
Klasyfikacja J E L: G32, G38.

\begin{abstract}
Abstrakt: Celem badania jest określenie kluczowych rynkowych i pozarynkowych czynników istotnych dla rozwoju polskiej branży producentów zielonej energii. Lepsze zrozumienie warunków działania producentów zielonej energii na polskim rynku jest i będzie przydatne w procesie modyfikacji polityki publicznej mającej wspierać rozwój obszaru energetyki odnawialnej. Wyniki prowadzonej analizy wskazują, że niezbędne dla rozwoju producentów energii odnawialnej jest odpowiednio prowadzona polityka publiczna, zwłaszcza przepisy dotyczące finansowych aspektów wspierania energii ze źródeł odnawialnych. Istotna jest także możliwość dostępu do innowacyjnych technologii sprawdzonych na innych rynkach, ze względu na brak doświadczeń w tym zakresie na rynku rodzimym. Badanie to jest jedną z pierwszych prób oceny efektywności finansowej przedsiębiorstw z branży odnawialnych źródeł energii na polskim rynku.
\end{abstract}

\title{
INTRODUCTION
}

Renewable energy is the energy obtained from natural and repetitive processes taking place in nature, from renewable non-fossil energy sources. It may comprise energy from water, wind, solar radiation, geothermics, solid biofuels, biogas and liquid biofuels as well as energy harvesting. The transition from traditional, based on raw materials, energy production into the production which is trying to replace fossil fuels with renewable energy carriers has - apart from unquestionable biological effects worldwide - a huge social importance, particularly crucial in Poland since the use of renewable sources of energy results in creating new jobs in production and technological equipment maintenance areas, as well as in production, preparation and transportation of biofules and in servicing the companies investing in RSE.

According to the European Renewable Energy Council, the share of energy derived from renewable sources of energy (RSE) in the total consumption in the EU amounted to $20.3 \%$ in 2011 (see figure 1). The recent dynamic development of RSE worldwide (average in EU-27 from 15,6 in 2007 to 20,3 in 2011) has been the result of adopting energy strategies in respective countries and the groups they constitute such as the EU ${ }^{1}$. However, it should be remembered that the development of this sector is driven by: technological progress and increasing awareness of the society which can see more and more benefits generated from the RSE development for itself and the surroundings.

1 The EU committed itself to reduce the total emission of carbon dioxide by at least $20 \%$ by 2020 in comparison to the level reached in 1990, or even by $30 \%$ if other developed countries commit themselves to similar reductions within the new global climate agreement. 
Figure 1. The share of renewable energy

in obtaining primary energy in general in selected EU member states in 2011

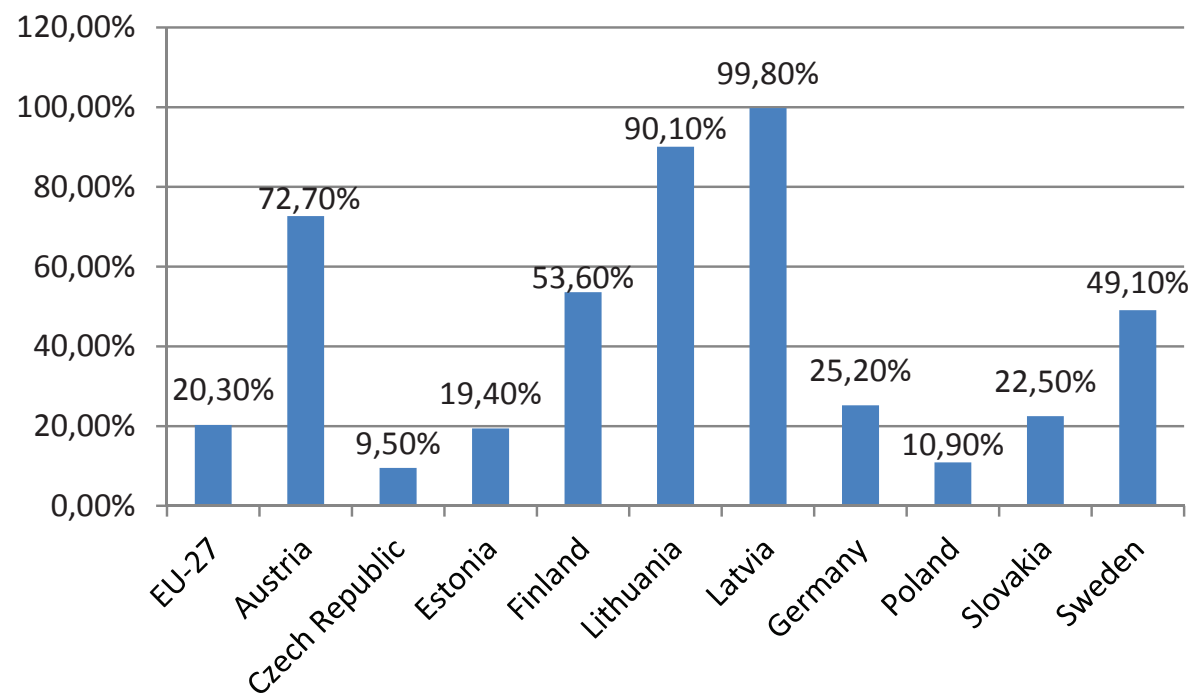

S o u r c e s: the author's own analysis based on GUS (Central Statistical Office) data.

In order to systematize the use of the six basic terms referring to RSE, suitable terminology provided by the Central Statistical Office (Pol. GUS) will be used in further sections of the paper. GUS, following its analyses of the way energy is obtained and used from Polish RSE (CSO, Energia ze źródeł odnawialnych), which are performed annually, distinguishes five basic sources of energy:

- energy directly obtained from solar radiation,

- energy directly obtained from wind,

- energy directly obtained from geothermal resources,

- energy directly obtained from water resources,

- energy obtained from municipal solid wastes,

- energy obtained from solid biomass, biogas and liquid bio-fuel.

The classification of obtained energy according to its sources in 2012 (see table 1) as well as suitable respective classification from previous years illustrate well a clear dominance of biomass among RSE available in Poland. The share of solid biomass is especially important, though in recent years this tendency has been said to decline slightly (from 50.2\% in 2011 to $48.1 \%$ in 2011). Quite similar data is observable in the Baltic states excluding Sweden. In the 
case of the latter, the share of solid biomass is only by a few percent higher than the average for the EU-27, which is a little lower than 50\% (see table 1).

Table 1. The classification of obtained energy according to selected sources in Poland in 2012 and the European Union in 2011 [\%]

\begin{tabular}{|l|c|c|}
\hline \multicolumn{1}{|c|}{ Source of energy } & Poland & EU-27 \\
\hline \hline solid biomass & 82.16 & 48.1 \\
\hline solar energy & 0.15 & 3.7 \\
\hline water energy & 2.06 & 16.3 \\
\hline wind energy & 4.80 & 9.5 \\
\hline biogas & 1.98 & 6.3 \\
\hline bio-fuel & 7.97 & 7.1 \\
\hline geothermal energy & 0.19 & 3.8 \\
\hline municipal waste & 0.38 & 5.2 \\
\hline heat pump & 0.31 & Bd \\
\hline \hline
\end{tabular}

S o u r c e s : the author's own analysis based on GUS.

The development of green power industry depends on a wide variety of factors. It is well reflected in publications concerning the problems of RSE in Poland, which take into consideration such common contexts as legal, technological, environmental or economic ones. Polish publications concerning economic conditions or the factors governing the development of Polish bioenergetics are not particularly abundant. Undoubtedly, it is worth supplementing such insufficient knowledge with foreign publications. Many of them encompass a wide space dimension (e.g. European) including an attempt to explain also Polish issues.

It seems that at least two clear tendencies may be distinguished among currently carried out research within which the conditions are strongly emphasized. The first research tendency focuses on the barriers and driving forces (stimulants and destimulants) for RSE or its particular segments development. Such a depiction is aimed at possibly complete identification of diversified developmental factors and their clear arrangement. The results may be quite general, though. The second tendency, slightly less frequently represented in scientific literature, tries to diagnose the situation at its source. Therefore, enterprises and their surroundings become the subject of a detailed analysis. The results here may, however, be somehow stigmatized with the peculiarity of 
analyzed subjects, which may impede the generalization of formulated conclusions. The discussion concerning present publications will begin the review of research recognized as the first of the above mentioned tendencies.

McCormick and Kåberger (2007) made an attempt to identify and analyze the barriers to bioenergetics in the European Union. As they said in the article published in 2007, one of the main challenges of the EU and its member states is answering the question: how to accelerate the implementation of power systems based on bioenergy to achieve earlier assumed objectives in terms of RSE and bioenergy. The following three conclusions are worth an attention in particular:

- some developmental barriers refer to all RSE, other barriers may apply only in power industry using biomass;

- key barriers to the development of bio-energy in the European Union are: economic conditions, know-how and institutional capacity, and supply chain coordination;

- there are no technical issues that represent key barriers for bio-energy.

In 2011 Jianbang, Gan and Smith (2011) published the article in which they identified some key factors that may have driven the difference in the shares of renewable energy in total primary energy supply among OECD countries for renewable energy in general and bioenergy in particular. The regression analysis proved that only market deployment policies and GDP had statistically significant effects on the supply of renewable energy or bioenergy. It turned out simultaneously, though welcomed with a slight disbelief by other researchers, that in the analyzed period: 'other factors such as research and innovation policies, market-based energy policies, energy prices, and R\&D expenditures did not play a significant role in enhancing renewable energy and bioenergy supply'.

In Poland, the assumptions concerning the development of green energy were specified in the administrative document titled The Strategy for RSE Development and in the following documents: Energy Policy for Poland until 2030 and The Power Engineering Program. The strategic aim of the state policy is to increase the use of renewable energy resources so that the share of RSE in the gross final energy consumption in 2020 would reach $15 \%$. At the end of 2010 the Council of Ministers adopted The National Renewable Energy Action Plan directly due to the EU directive. The plan included the forecast of a 15.5\% share of RSE in the gross final energy consumption in 2020 in Poland achieved in a sustainable way with regard to many factors such as: renewa- 
ble energy resources and raw materials used to produce fuels and electrical power systems.

Apart from the documents prepared by the authorities, the issue of RSE development is also discussed by researchers. As far as Polish publications discussing the conditions for the development of Polish RSE are concerned, the article by Bielski (2011) should be mentioned here. The author focused on presenting economic and legal conditions as well as introduced technological conditions for processing biomass. In conclusion, he noticed that the introduction of legal regulations in Poland concerning RSE was mainly the consequence of adjusting the state's law to the EU requirements. Due to the general character of EU directives 2009/28/EC on the promotion of the use of energy from renewable sources, state solutions could be modified with a relative freedom.

A very interesting conclusion referring to the formulation of public policy in terms of RSE was introduced by Gawlik, Mokrzycki and Ney (2007). They think that renewable energy sources in Poland are strictly connected with local societies. Therefore, the development of RSE should be adjusted to the conditions dominating in a given region. In this sense, there is no justification for the same scale or pace of development of RSE in the whole country.

\section{RESEARCH METHODS AND RESEARCH PROCESS}

The research process was divided into two stages. The qualitative research was conducted in the first stage which involved the analysis of source documents which justify the support policy for RSE producers (green certificates and auction systems). Next, particular sources of 'green' energy were analyzed with regard to the structure of final products and the production process was assessed (divided into continuous and periodic production). The second stage involved quantitative research to assess the level of support (green certificates prices) and its changes. Here, the indices created for property rights (green certificates) were used. Both the prices and rates of return on property rights (green certificates) prices were analyzed. Their average prices and their scope were defined as well. The volatility was also presented in the form of logarithmic daily returns for the above mentioned indices according to the formula: $\left(\mathrm{R}=100^{*} \ln (\mathrm{p} / \mathrm{p})\right)$. The rates of return were established for three indices created for green certificates: the OZEX_A index for session transactions, the OZEX_A_TP index for OTC deals and the OZEX_A_POLPX index for sessions and OTC trading. Too limited number of the observations made (63-70) does not al- 
low to draw any general conclusions, however, it constitutes a solid ground for further research.

\section{RESULTS AND CONCLUSIONS DRAWN FROM THE RESEARCH PROCESS}

In Poland, the fundamental legal provisions concerning renewable energy are specified in the Energy Law Act. The legislator imposed an obligation on energy companies to purchase electrical power and heat obtained from RSE. An electrical energy seller whose network is connected with a renewable source must purchase from this source any amount of electrical energy produced by this source. The price of energy a power plant pays for repurchasing electrical power cannot be lower than the average price of electrical energy on the competitive market in the previous year, and the price is announced by the President of the Energy Regulation Office on annual basis. In practice, it generates the obligation to purchase certificates of origin for the producers of 'black' energy or to pay a substitution fee settled by the Energy Regulation Office. At present, a new bill is being discussed. It assumes the transition from the current system of subsidizing each present production of energy from renewable sources into the auction system in which the one who proposes a lower price of such energy will obtain a guarantee of purchasing energy even for 15 years paying the suggested price indexed by the inflation rate. The Ministry of Economy assumes that the act will come into force at the beginning of 2015 and the auctions to purchase 'green' energy will be announced at least once a year. The Minister of Economy is supposed to announce earlier a so called reference price, i.e. the maximum price which may be offered during an auction as well as the amount of energy which will be supported by the country in a given year. The bill does not assume, however, supporting co-burning of biomass with coal in huge energy blocks (the proposed support in the act amounts to 50\%), which today constitutes $80 \%$ of the Polish 'green' energy. However, the support is to be given to so called dedicated installations of multi-fuel burning in which particular types of fuel are provided by separate lines.

The analysis of final products and the continuity of productions shows that depending on the RSE source, the final products are diversified (their number depends on the source of RSE). Only the energy obtained from wind and water have one final source and this is electrical energy. Bio-fuels and solid bio-mass constitute two sources of RSE whose final effects are diversified. Bio-fuels are produced from organic raw materials (from biomass or bio-degradable frac- 
tions of wastes). These include mainly the following products: bio-ethanol, biodiesel, bio-methanol, bio-dimethylether, bio-ETBE bio-MTBE. Liquid bio-fuels can also be used as natural plant oils. The above mentioned products are used as bio-components added to engine fuels produced from crude oil. The most commonly used additives include: bio-ethanol (added to gasoline engine fuel) and biodiesel (added to diesel oil). Bio-fuels can be further divided into bio-liquids (other liquid bio-fuels). Bio-liquids are liquid fuels used for energy purposes other than in transportation including electrical, heat and cold energy produced from biomass. In the case of solid biomass, the final effect of the production is also charcoal.

Table 2. Type of final products depending on RSE type

\begin{tabular}{|l|l|l|}
\hline \hline \multicolumn{1}{|c|}{ Source of energy } & \multicolumn{1}{|c|}{ Final products } & \multicolumn{1}{c|}{ Continuity of production } \\
\hline \hline solid biomass & $\begin{array}{l}\text { Heat energy } \\
\text { Electric energy } \\
\text { Charcoal }\end{array}$ & Continuous production \\
\hline solar energy & $\begin{array}{l}\text { Heat energy } \\
\text { Electric energy }\end{array}$ & Periodic production \\
\hline water energy & Electric energy & Continuous production \\
\hline wind energy & Electric energy & Periodic production \\
\hline biogas & $\begin{array}{l}\text { Flammable gas } \\
\text { Electric energy } \\
\text { Heat energy } \\
\text { Electric energy }\end{array}$ & $\begin{array}{l}\text { Continuous production } \\
\text { Eleat energy }\end{array}$ \\
\hline bio-fuel & Continuous production \\
\hline geothermal energy & Continuous production \\
\hline \hline
\end{tabular}

S o u r c e : the author's own analysis.

However, not every product obtained from RSE is supported by the Act, but only electrical power by granting so called property rights. Property rights result directly from certificates of origin and are created simultaneously when a particular type of a certificate is registered in the record account of the producer. The number of certificates of origin equals the amount of electrical power given in a certificate of origin, however, one certificate is equal to $1 \mathrm{MWh}$ of electrical energy. Hence, the amount of produced energy determines the level of support for the producers of green energy. The nature of producing solar and wind energy is rather seasonal. It depends on the amount of solar radiation 
and the strength of wind. Discontinuous production forces the producers to take into consideration natural conditions while selecting the location for such a source of energy, otherwise they will risk less amount of produced electrical energy and, therefore, lower support. The same happens in the case of geothermal energy and wind energy, though the production process here is continuous, still the location depends on natural resources. As far as biogas and solid biomass are concerned, their production is limited due to the access to raw materials. The closer the production of raw materials used to produce biomass is located, the more efficient the process is, and this is how transportation costs may be limited.

The average value of indices reflecting the prices of green certificates for the OZEX_A index equals PLN 179, for OZEX_A_TP - PLN 213, and for OZEX_A_POLPX - PLN 203 (see table 3). The last two indices are of higher volatility due to the fact that package transactions are concluded partially under long-term contracts and in high volumes. Hence, the high trading volume for package transactions reflected in the OZEX_A_TP index determines the value of the OZEN_A_

Table 3. Selected statistics for RSE indices

\begin{tabular}{|c|c|c|}
\hline OZEX_A & OZEX_A_TP & OZEX_A_POLPX \\
\hline \multicolumn{3}{|c|}{ Average standard deviation of rates of return } \\
\hline 0.0422 & 0.1862 & 0.1792 \\
\hline \multicolumn{3}{|c|}{ Volatility corridor in PLN } \\
\hline$\{133.63 ; 229.95\}$ & $\{144.16 ; 265.00\}$ & $\{150.42 ; 245.69\}$ \\
\hline \multicolumn{3}{|c|}{ Average prices in PLN } \\
\hline 179 & 213 & 203 \\
\hline \multicolumn{3}{|c|}{ Average volume of return in PLN } \\
\hline 53944 & 157739 & 203040 \\
\hline \multicolumn{3}{|c|}{ Number of observations } \\
\hline 70 & 63 & 70 \\
\hline
\end{tabular}

S o u r c e : the author's own analysis.

POLPX index. The average volatility of rates of return for the OZEX_A index is four and a half times lower for the OZEX_A_TP and OZEX_A_POLPX indices. Therefore, the risk of price stability is higher (see figure 2 , figure 3 ), whe- 
reas the range of price volatility for the OZEX_A index equals PLN 96.32, for OZEX_A_TP PLN - 120.84 and for OZEX_A_POLPX - PLN 95.27. The range of price volatility is about $25 \%$ higher for package transactions than for session transactions.

The majority of transactions concluded on the Energy Exchange are package transactions. Since they are concluded as agreements for a definite period, usually for one or a few years, the prices reflect the supply and demand for green certificates on the day when the agreement was signed. The current demand for green certificates is reflected in the OZEX_A index. The prices do not undergo that high volatility, however, the fall of prices is visible in the analyzed period. The decrease is caused by increased supply of green certificates derived from co-burning, which results from the producers of 'black' energy policy.

Figure 2. The values of the OZEX_A, OZEX_A_TP and OZEX_A_POLPX indices in PLN from April 30, 2013 to January 16, 2014

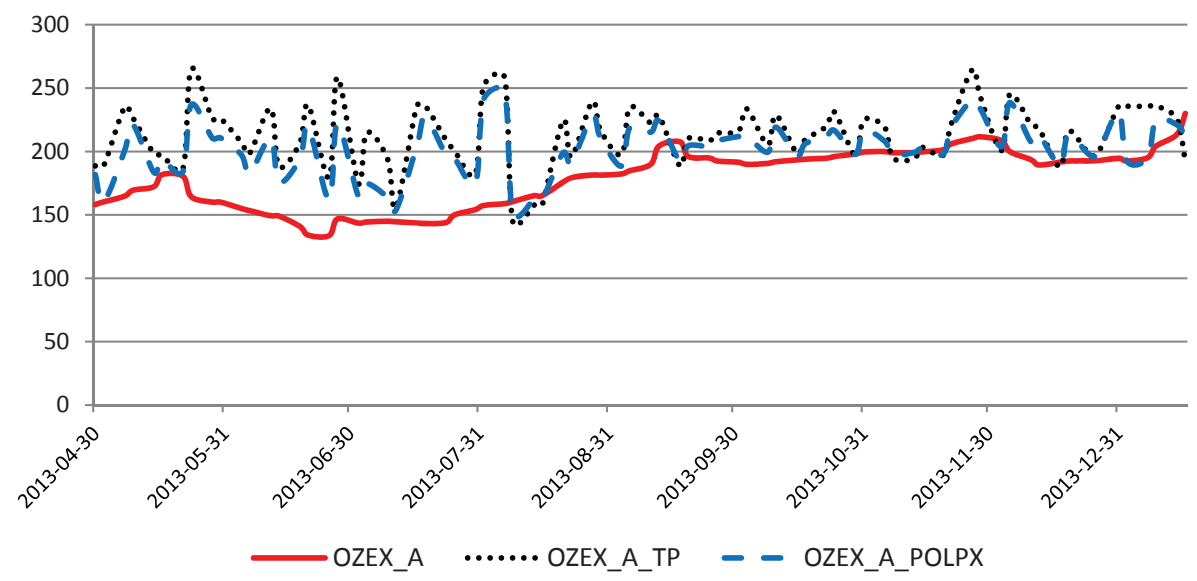

S o u r c e s : the author's own analysis on the basis of Polish Power Exchange data. 
Figure 3. Rate of return from the OZEX_A, OZEX_A_TP and OZEX_A_POLPX indices from April 30, 2013 to January 16, 2014

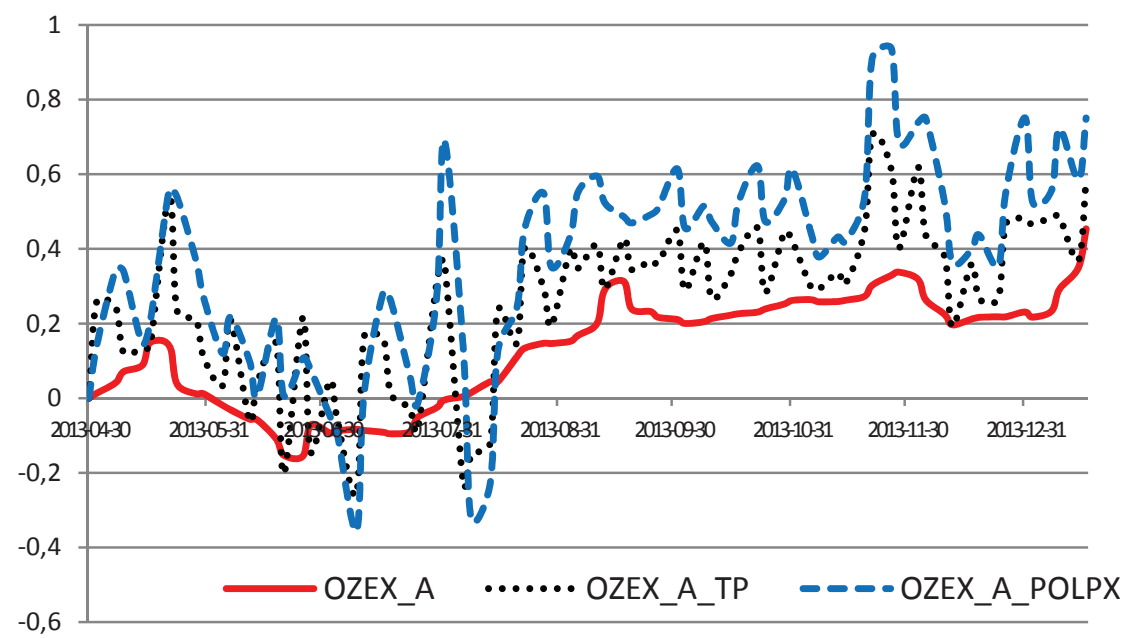

S o u r c e s: the author's own analysis on the basis of Polish Power Exchange data.

The state policy of auction-based system for selling green certificates as well as limited support for co-burning should influence prices stability in a long term and at the same time it will facilitate a more effective management of the structure and size of revenues in enterprises operating in the RSE sector. The former state policy (though effective due to the implementation of the EU directive) resulted in the decrease of market prices for 'green' certificates mainly due to the co-burning system. The technologies especially used while obtaining energy from solid biomass, geothermal energy or biogas are highly capital-intensive and require financial support also from external sources, whereas the statutory stabilization increases the credit score of such enterprises.

\section{REFERENCES}

Bielski S. (2011). Conditions of Biomass Production for Energy Generation Purposes in Poland. Folia Oeconomica Stetinensia, vol. 10, no. 1, 238-249. http://dx.doi. org/10.2478/v10031-011-0003-4.

Central Statistical Office (2012), Energia ze źródeł odnawialnych w 2012 roku, Warszawa, 13-14, http://www.stat.gov.pl/cps/rde/xbcr/gus/se_energia_zrodla_odnawialne_2012.pdf (accessed: 14.01.2014). 
Energy Policy for Poland until 2030 (2009), http://www.swiadomieoatomie.pl/media/ 21853/polityka_energetyczna_polski_do_2030.pdf: (accessed: 27.03.2014).

Gawlik L., Mokrzycki E., Ney R.(2007), Renewable Energy Sources in Poland - Conditions and Possibilities of Development, http://www.worldenergy.org/documents/ p001106.doc (accessed: 24.08.2013).

Główny Urząd Statystyczny (2012), Energia ze źródeł odnawialnych w 2011 roku, Warszawa, 13-14, http://www.stat.gov.pl/cps/rde/xbcr/gus/se_energia_zrodla_odnawialne_2011.pdf (accessed: 14.01.2014).

Jianbang Gan, Smith C.T. (2011). Drivers for Renewable Energy: a Comparison among OECD Countries. Biomass and Bioenergy, vol. 35, no. 11, 4497-4503. http://dx.doi. org/10.1016/j.biombioe.2011.03.022.

McCormick K., Kåberger T. (2007). Key barriers for bioenergy in Europe: Economic conditions, know-how and institutional capacity, and supply chain co-ordination. Biomass and Bioenergy, vol. 31, no. 7, 443-452.

Polish Power Energy, http://www.polpx.pl/en (accessed: 27.03.2014). http://dx.doi. org/10.1016/j.biombioe.2007.01.008.

Rogulska M., Oniszk-Poplawska A., Pisarek M. (2005), Potential and trading opportunities for biomass in Poland, http://www.oekosozial.at/uploads/tx_osfopage/Rogulska_long.pdf (accessed: 24.08.2013).

The Act of 10 April 1997 Energy Law, Journal of Laws of 2012, pos. 1059.

The National Renewable Energy Action Plan (2010), http://www.mg.gov.pl/files/upload/12326/KPD_RM.pdf (accessed: 27.03.2014).

The Power Engineering Program (2006), http://www.eplan.info.pl/folder.2006-11-02. 4284373342/Program_dla_elektroenergetyki_2006.pdf (accessed: 27.03.2014).

The Strategy for RSE Development (2000), http://www.pga.org.pl/prawo/strategia-OZE. pdf (accessed: 27.03.2014). 